\title{
Overview of arsenic distribution in some part of Biu Volcanic Province North-Eastern Nigeria
}

\author{
Usman, Adamu Mohammed ${ }^{1,}$, Lar, Uriah Alexander ${ }^{2}$ \\ ${ }^{1}$ National Steel Raw Materials Exploration Agency, Kaduna, Kaduna-Nigeria \\ ${ }^{2}$ Department of Geology and Mining University of Jos, Jos-Nigeria
}

\section{Email address:}

adamuusman@gmail.com (Usman, A. M.), ualexanderlar@yahoo.co.uk (Lar, U. A.)

\section{To cite this article:}

Usman, Adamu Mohammed, Lar, Uriah Alexander. Overview of Arsenic Distribution in some Part of Biu Volcanic Province North-Eastern Nigeria. Earth Science. Vol. 2, No. 6, 2013, pp. 145-148. doi: 10.11648/j.earth.20130206.15

\begin{abstract}
Overexposure to arsenic can cause various diseases such as cancer of (skin, lung, bladder, and kidney), hair loss and nails deformity. These diseases are common among adults, youth and children in some rural communities in Biu Volcanic Province North-Eastern Nigeria. This is what motivated the Authors to investigate the concentration of arsenic in surface and ground waters of Biu volcanic environment, northern eastern Nigeria and to delineate areas of high risk to arsenic exposure. Thirty seven water samples; thirteen surface water samples and twenty four ground water samples were analyzed using Inductively Coupled Plasma Optical Emission Spectrometry (ICP-OES) at Geochemistry Laboratory, University of Jos, Nigeria. Arsenic concentrations range from 0.03 to $0.477 \mathrm{mg} / \mathrm{L}$ in the surface water and 0.006 to $0.424 \mathrm{mg} / \mathrm{L}$ in the ground water. This study indicates that people in Yimirshika Village might be at a considerable risk of arsenic poisoning.
\end{abstract}

Keywords: Arsenic Distribution, Volcanic Province, Health Hazard, Biu, Nigeria

\section{Introduction}

The Biu volcanic province constitutes one of the largest volcanic provinces in Nigeria. It marks the structural culmination between the Benue and the Chad sedimentary basins (fig.1); it lies in the north eastern Nigeria. The province covers a superficial area of $5000 \mathrm{Km} 2$ with a thickness of $250 \mathrm{~m}$, made up of several simple volcanoes with very large craters (caldera) of greater than $1 \mathrm{~km}$, suggesting that quite a large volume of magma, volcanic ash and pyroclastic materials erupted.

Through physical and chemical weathering processes, rocks break down to form the soils on which the crops that constitute the food supply are raised for humans and animals consumption. Drinking water travels through rocks and soils as part of the hydrological cycle and in the process leached elements in solution (Lar, 2009). Volcanism and related igneous activities re distribute some of the harmful elements, such as arsenic, beryllium, cadmium, mercury, lead, radon, and uranium. Almost all metals present in the environment have been biogeochemically cycled since the formation of the Earth. Human activity has introduced additional processes that have increased the rate of redistribution of metals between environmental compartments.
However, over most of the Earth's land surface the primary control on the distribution of metals is the geochemistry of the underlying and local rocks except in all but the worst cases of industrial contamination and some particular geological situations.

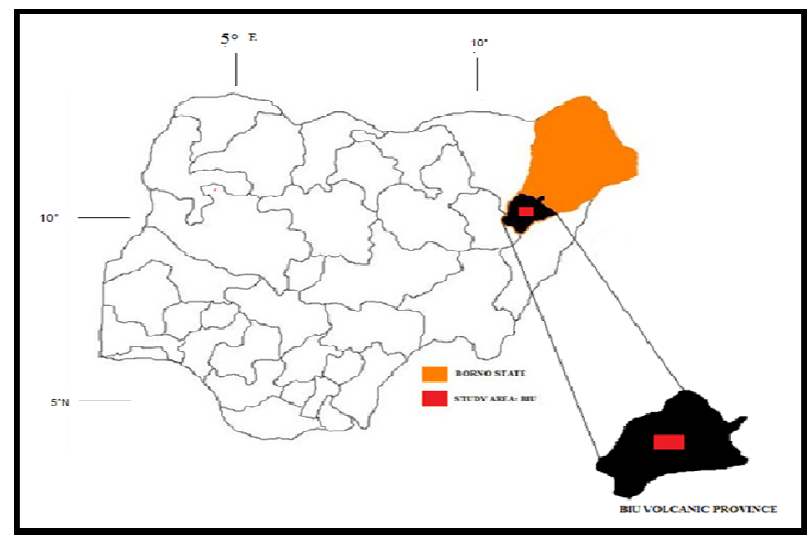

Fig 1. Map of Nigeria showing the location of the study area

The purpose of this study is to determine the distribution of arsenic in the natural waters of Biu Volcanic Province Nigeria, and the possible health hazard to the inhabitants. 


\section{Geology and Hydrogeology of Biu Volcanic Province}

\subsection{Geology}

Biu Plateau is situated on the structural and topographic divide between the Benue and Chad sedimentary basins. The structural divide is a broad E-W ridge or swell of basement, which extends to the western edge of the Biu Plateau. The two basins are divided by a sub-surface size, the Zambuk ridge to the west (Carter et al., 1963).

The basalt of the Biu Plateau mainly overlies Basement rocks. They are mostly occurring as "flood basalts" in a number of flows and in fact cover nearly $85 \%$ of the area with its centre around Biu (Turner, 1978). The basalt at some places has built up large number of flows. The dimension of the flows and the marked absence of pyroclastics in and around Biu, Tum, Marama, and Shaffa areas, indicate that the eruption of basaltic magma in these places was not violent. However, the basaltic sequence in the North-western part of Biu is surrounded by several youthful scoria, cinder cones, tephra rings etc., the pyroclastics are generally restricted to the area west of Biu- Damaturu road, suggesting that the eruptions in these places are violent in nature.

\subsection{Hydrogeology of the Study Area}

\subsubsection{Introduction}

The water resources of the study area can be divided into surface and groundwater resources. The surface water of this area occurs in the form of streams and lakes. They serve as water supply sources for both drinking and domestic uses. Most of the streams are seasonal. The streams and lakes are recharged by direct precipitation during the rainy season.

\subsubsection{Surface Water}

\subsubsection{Lake Tila}

The only permanent body of water is Lake Tila situated at Kwaya Bura village about thirteen kilometers to the south-west of Biu. The lake occupies a crater a short distance west of Mount Tila.

The lake-level in the height of the dry season is only one meter below what appears to be the peak level bench-mark. The high water level each year is dependent on the rainfall and it can be assumed that it ranges within one meter, (Du Preez, 1965).

The lake receives very little runoff during the rains and the rise of the lake level is due mainly to direct precipitation. There is little seepage zone around the shore which flows continuously into the lake. Shallow percolation wells dug into the zone constitute the main domestic water supply for several villages in the vicinity.

Analyses of water samples from Lake Tila and from the shallow seepage wells along the shoreline carried out by the (Du Preez, 1965) are given in. The analysis of the lake water shows a high concentration of sodium carbonate, and comparatively low sodium chloride content. In the water from the seepage wells, sodium carbonate probably also predominate, while sodium chloride is negligible. Owing of the high carbonate content the lake water is unsuitable for irrigation. It is estimated that the amount of soda in the lake is in the order of about 2,000 tons, but it is doubtful whether it is of any economic value, (Du Preez, 1965).

\subsubsection{Perennial Stream Water}

Most of the rivers in Biu dry up for a part of the year, but a considerable number of streams rising on the basalt Plateau are weakly perennial some of the streams are fed by seepage springs which issues from the basalts.

These discharges are small and are absorbed in the alluvium on reaching the low-lying country below the basalt Plateau. Permanent pools are frequently present in these streams, and they provide water supplies for neighboring villages.

\subsubsection{Groundwater in the Basalts}

The basalts are usually strongly jointed and fissured. The earlier flows, usually consist of dense compact basalt, while the early flows are irregular jointed. The joints serve as loci of weathering and as channels for the circulation and storage of groundwater (Du Preez, 1965). The compact basalts are incapable of storing water, the groundwater held in the joints gives rise to numerous small springs on the higher parts of the Plateau.

The basalts form the most important aquifer in Biu Plateau. The amount of water obtained in them depends on the degree of decomposition, jointing and the nature of the rock. The basalts show a superficial weathered zone consisting of black-grey and brown clay with residual boulders of partially decomposed rock.

The scoriaceous and amygdaloidal basalts usually weather to brown and blue clays which tend to disintegrate on exposure to the atmosphere. Moderate amounts of water may be present in the basalt alluvium but in general the quantity of water available is small and the water table is subject to considerable variation. Many villagers get their water partly or wholly from this source during the dry season. The water from this source can be obtained through hand dug wells which were seen all over the area and few boreholes.

\subsubsection{Data Collection}

Data of the water table was obtained by field measurement of static water levels in wells within the study area, as well as the geographical positions and elevations at various locations.

\subsubsection{Data Processing}

Coordinates of the observed wells and well elevations were manipulated using a computer program (sufer 8). The $\mathrm{X}$, $\mathrm{Y}, \mathrm{Z}$ coordinates in the surfer 8 is entered as longitude, latitude and elevation respectively, from which the computer program plots a water table contour map (figure 2). 


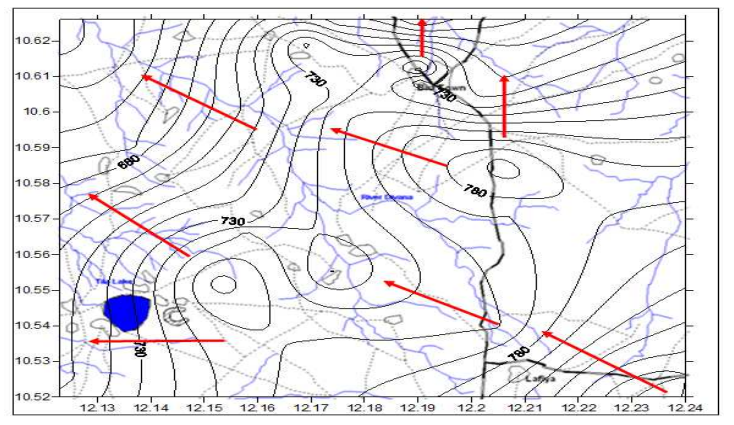

Fig 2. Groundwater Contour Map of the study area indicating direction of Water Flow (resent study)

\subsubsection{Interpretation of Groundwater Map}

A water table contour map shows the elevation and the configuration of the water table at a certain data. The map is prepared by plotting the absolute water levels of all observation points of equal water table elevation. This water table contour map (figure 2) is an important tool in groundwater investigations as one can derive from it the gradient of the water table and the direction of the groundwater flow.

Generally, the pattern of groundwater flow follows the surface topography with seasonal variations in water levels characterized by rising water levels during the wet months and declining water levels during the dry months.

\section{Methodologies}

\subsection{Field Sampling}

Sampling was accomplished during the dry season (March 28-April 25). A total of thirty seven (37) water samples and thirteen (13) soils samples were collected over an area of $150 \mathrm{~km}^{2}$ for analysis to determine their elemental concentrations.

The sampling locations of the study area are presented in (fig. 3).

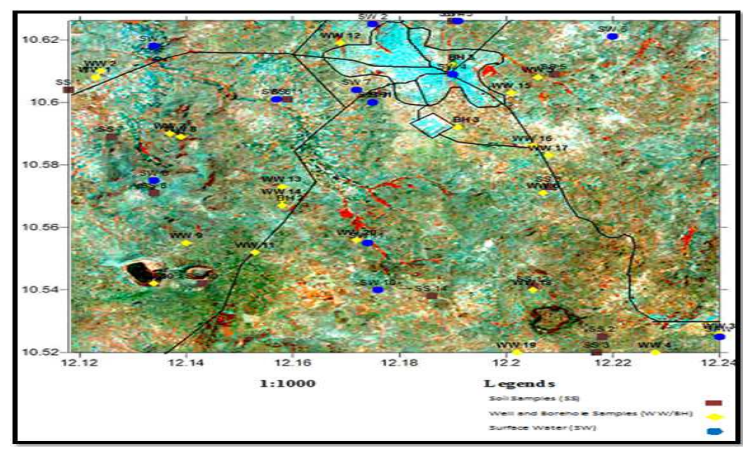

Fig 3. sampling locations of the study area (This study)

In view of the usual low trace element concentrations in water, various measures were taken to prevent the slightest contamination in the collected samples. $250 \mathrm{ml}$ polyethylene bottle capacity containers were used for the collection of samples. Bottles were first washed with a mixture of acid and distilled water $\left(1 \% \mathrm{HNO}_{3}\right)$. The bottles were finally rinsed with distilled water and kept to dry in an oven at $25^{\circ} \mathrm{C}$.
One important step taken was the immediate wrapping of the bottle with sterilized thin film with the top of the bottle folding over a non-contaminating stiffened material attached to the twisted end. With these procedures the bottles were protected and ready for sample collection.

After the sample was collected, the old thin film was removed and a new one re-wrap. All samples collected were labeled according to location, nature of sample, date of collection and number. Samples collected were kept in the refrigerator at room temperature $\left(23^{0} \mathrm{C}\right)$.

\subsection{Laboratory Analysis}

Analysis of the water samples was carried out using Inductively Coupled Plasma Optical Emission Spectrometry (ICP-OES) at Geochemistry Laboratory, University of Jos, Nigeria, to determine the major and trace elements concentrations.

\subsection{Results and Discussion}

The range of arsenic values from different water sources is displayed in Table 1.

Table 1. Arsenic Concentration in natural water

\begin{tabular}{|c|c|c|}
\hline Samples & Locality & As (mg/L) \\
\hline BH1 & Waka & 0.224 \\
\hline $\mathrm{BH} 2$ & Hena & 0.089 \\
\hline $\mathrm{BH} 3$ & Army Barrack & 0.039 \\
\hline $\mathrm{BH} 4$ & Biu BCJ & 0.070 \\
\hline W1 & BCJ & 0.040 \\
\hline W2 & Wakama & 0.315 \\
\hline W3 & Yimirshika & 0.037 \\
\hline W4 & Waka & 0.023 \\
\hline W5 & Biu & 0.227 \\
\hline W6 & Biladega & 0.066 \\
\hline W7 & Tabra Fulani & 0.083 \\
\hline W8 & Malan & 0.039 \\
\hline W9 & Tila & 0.059 \\
\hline W10 & Tila & 0.043 \\
\hline W11 & Tila & 0.006 \\
\hline W13 & Hena & 0.123 \\
\hline W14 & Hena & 0.229 \\
\hline W16 & Yimirshika & 0.136 \\
\hline W17 & Gwarta & 0.290 \\
\hline W18 & Kunar & 0.424 \\
\hline SW1 & Wakama & 0.067 \\
\hline SW2 & Waka & 0.389 \\
\hline SW3 & Waka & 0.087 \\
\hline SW5 & Tabra Fulani & 0.041 \\
\hline SW6 & Hena & 0.074 \\
\hline SW7 & Hena & 0.116 \\
\hline SW8 & Hena & 0.067 \\
\hline SW9 & Army Barrack & 0.021 \\
\hline SW10 & Army Barrack & 0.032 \\
\hline SW11 & Kunar & 0.036 \\
\hline SPW & Yimirshika & 0.477 \\
\hline
\end{tabular}

It is noted that arsenic is concentrated in all the water bodies above WHO admissible standard of $0.01 \mathrm{mg} / \mathrm{L}$.

Range of arsenic concentration in surface water is from 0.02 to $0.0477 \mathrm{mg} / \mathrm{L}$. The lowest concentration of $0.02 \mathrm{mg} / \mathrm{L}$ was observed in Takwa village while the highest concentration of $0.477 \mathrm{mg} / \mathrm{L}$ was detected in surface spring water in Yimirshika village. Concentration of arsenic varied 
from $0.01-0.424 \mathrm{mg} / \mathrm{L}$ in well water samples collected from various sites. The lowest concentration of $0.01 \mathrm{mg} / \mathrm{L}$ was detected at Tila while the highest concentration of 0.424 $\mathrm{mg} / \mathrm{L}$ was determined from Kunar.

The observed concentration of arsenic in borehole water samples collected from various sites in Biu ranged from 0.04-0.2 $\mathrm{mg} / \mathrm{L}$. The highest concentration of $0.2 \mathrm{mg} / \mathrm{L}$ was recorded in Waka Biu while the lowest concentration of 0.04 $\mathrm{mg} / \mathrm{L}$ was observed in Biu Army Barrack. Concentration of arsenic and its spatial distribution in surface and groundwater is shown in Fig 4.

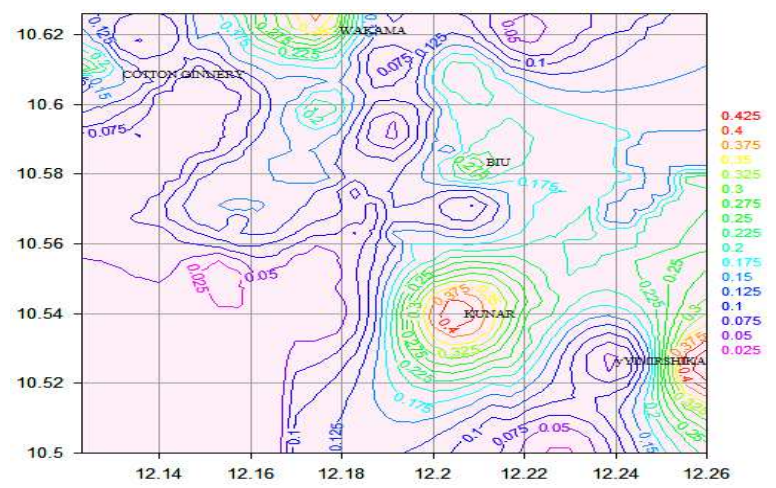

Fig 4. Shows concentration of arsenic and its spatial distribution in surface and groundwater

\section{Trace Element Exposures}

This study discover the concentration of arsenic from 0.1 to $0.48 \mathrm{mg} / \mathrm{L}$, the high concentration will be hazardous to the inhabitants due to long time exposure through ingestion of food and water. According to Maloney, 1996 and Smedley and Kinniburgh, 2002, the overexposure to this element can cause various diseases such as cancer (skin, lung, bladder, and kidney), hair loss and nails deformity. This is in conformity with the present study in which some of the inhabitant's shows manifestation of some of these diseases which may be linked to arsenic toxicity.

\subsection{Arsenic Concentrations in Waters and Effects on Health in Biu Volcanic Province North-Eastern Nigeria}

The World Health Organization 2008, stated that safe limit for arsenic in drinking water is 0.01 , it is clear that excessive arsenic is being consumed in drinking water at; Waka $(0.224$ and $0.389 \mathrm{mg} / \mathrm{L})$, Hena $(0.116,0.123$ and 0.229 $\mathrm{mg} / \mathrm{L})$, Yimrshika (0.136 and $0.477 \mathrm{mg} / \mathrm{L})$, Wakama $(0.315$ $\mathrm{mg} / \mathrm{L})$, Biu (0.227 mg/L) and Kunar (0.424 mg/L). These areas are delineated as high risk zone to arsenic exposure.

For example the inhabitant of Yimirshika relies on their Spring Water which contains unsafe levels of dissolved arsenic for drinking, cooking and other domestic purposes. These findings indicate that they are over-exposed to this toxic metal through the ingestion of water and food.

Due to long time exposure, few of the inhabitants show manifestations of nail deformity (nail thickening and brittleness), and hyper-pigmentation of the skin and hand palms. Others present various forms of skin diseases (especially skin growth) which all could be attributed to exposure to arsenic toxicity. Plate 1-3 shows nails deformation and skin problem.

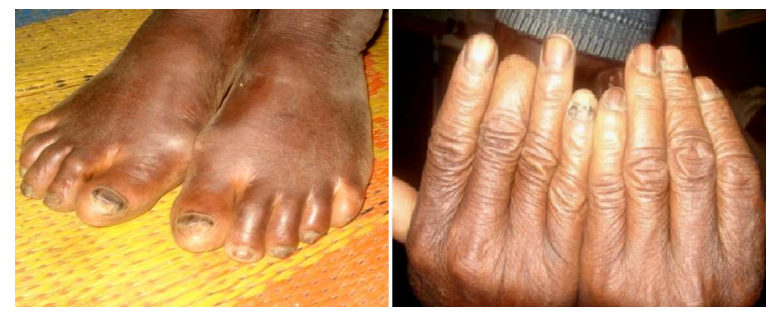

Plate 1 and 2. Shows deformed nails due to arsenic toxicity $\left(12^{\circ} 14 \square 41.4^{\prime} 10^{\circ}\right.$ $\left.31 \square 52.2^{\prime \prime}\right)$

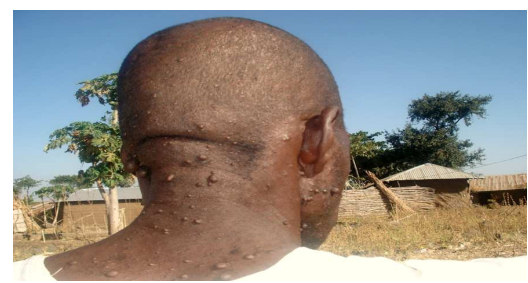

Plate 3. Growth on skin due to arsenic toxicity (12 $\left.14 \square 41.4^{\prime} 10^{\circ} 31 \square 52.2^{\prime \prime}\right)$

\section{Summary and Conclusions}

Areas identified with high arsenic in surface and groundwater of the province shows that the inhabitants of these areas have symptoms of arsenic exposure, such as diabetes, loss of hearing, hair loss, deformed nails and various skin problems like: rashes, abnormal growth, skin lesion and roughness.

\section{References}

[1] Carter, J. D., Baber, W. D., and Tait, E.A. (1963). The Geology of part of Adamawa, Bauchi and Borno provinces in North Eastern Nigeria. Bull. Geol. Survey, Nigeria. Bull. No. 30. p. 13-80.

[2] Du preez, J.W., and Barber, D. F. M. (1965). The Distribution and Chemical Quality of Groundwater in Northern Nigeria. Bull. Geol. Surv. Nigeria, 36, 93p.

[3] Lar, U.A., 2009: Trace Element and Health; Some Case Studies from Nigeria. Nigerian Mapping Technical Assistance Programmed, Kaduna (2009).

[4] Maloney M. Arsenic in dermatology. 1996. Dermatol Surg; 22:301-304.

[5] Smedley, P. L., Kinniburgh DG (2002). "A review of the source, behaviour and distribution of arsenic in natural waters". Applied Geochemistry 17 (5): 517-568. 1-4.

[6] Turner, D. C., 1978. Volcanoes of the Biu Basalts, North eastern Nigeria. Jour. Min. Geol. Vol. 15. PP. 49-62

[7] World Health Organization. (2008). Guidelines for drinking water Science, 198. 